\title{
PENGEMBANGAN MODUL PEMBELAJARAN BIOLOGI MATERI EKOSISTEM BERBASIS PENDEKATAN CONTEXTUAL TEACHING AND LEARNING (CTL)
}

\author{
Ummu Kalsum ${ }^{1}$, Muhammad Khalifah Mustami2 ${ }^{2}$, Wahyuni Ismail ${ }^{3}$ \\ 1,2,3Fakultas Tarbiyah dan Keguruan, UIN Alauddin Makassar \\ 1,2,3Kampus II: Jl. H. M. Yasin Limpo No 36 Samata-Gowa, Sulawesi Selatan, 92118 \\ Email: kalsumummu307@gmail.com¹, muhkhalifahmustami@gmail.com², \\ wahyuni.ismail@uin-alauddin.ac.id ${ }^{3}$
}

\begin{abstract}
Abstrak:
Penelitian ini bertujuan mengembangkan modul biologi berbasis pendekatan Contextual Teaching and Learning (CTL) yang valid, efektif, dan praktis. Penelitian ini merupakan penelitian pengembangan (Research and Development) yang mengacu pada model pengembangan 4-D atau model Thiagarajan yang dimodifikasi menjadi model 3-D, yakni tahap define (pendefinisian), design (perancangan), dan develop (pengembangan). Subjek uji coba dari penelitian ini yaitu peserta didik kelas VII SMP Negeri 2 Bajeng Barat. Instrumen penelitian yang digunakan dalam pengumpulan data dibagi atas 3 yaitu instrumen uji kevalidan berupa lembar validasi, instrumen uji kepraktisan berupa angket respon peserta didik, dan instrumen uji keefektifan berupa tes hasil belajar. Data dianalisis dengan menggunakan analisis deskriptif kualitatif dan kuantitatif (mix method). Berdasarkan data uji coba kevalidan modul yang direvisi sebanyak 3 kali, modul memenuhi kategori valid dengan skor rata-rata 3.39, untuk uji coba kepraktisan modul diperoleh nilai rata-rata 3.57 termasuk kategori sangat praktis dan setelah dilakukan uji coba keefektifan modul memenuhi kategori efektif untuk digunakan dengan perolehan nilai rata-rata 80.62, dengan jumlah siswa yang tuntas dalam proses pembelajaran adalah 28 orang atau sekitar $87.5 \%$ sedangkan yang tidak tuntas sebanyak 4 orang atau sekitar $12.5 \%$. Hal ini mengindikasikan bahwa modul yang dikembangkan masih belum sempurna namun layak untuk digunakan.
\end{abstract}

\begin{abstract}
:
The aims of the research were to develop a valid, effective and practical biologybased Contextual Teaching and Learning (CTL) module. This research is a research development (Development and Development) which refers to 4-D development model or Thiagarajan model that is modified into 3-D model, ie define, design and develop. The subject of this research is the students of class VII of SMP Negeri 2 Bajeng Barat. The research instrument is divided into 3 namely the validity test instrument in the form of validation sheet, the practicality test instrument in the form of a questionnaire of the learners' response and the effectiveness test instrument in the form of learning test. The data obtained were then analyzed using qualitative and quantitative descriptive analysis (mix method). Based on
\end{abstract}


data of validity test of 3 times revised modules, it shows that the module meets the valid category with the mean score of 3.39 , for modality practicality module obtained the mean score of 3.57 which belongs to very practical category and for effectiveness test of the module obtained effective category with the mean score of 80.62 , with the total number of students who achieved minimum mastery criterion were 28 people or about $87.5 \%$ while 4 of them have not achieved minimum mastery criterion or about $12.5 \%$. This indicates that the module developed is still not perfect, but it is feasible to use.

Kata kunci: Contextual Teaching and Learning, Modul, Pengembangan.

PEMBELAJARAN biologi terkait cara mencari tahu, menemukan dan memahami gejala alam sekitar secara sistematis. Pembelajaran biologi tidak hanya bersifat penguasaan sekumpulan informasi pengetahuan berupa konsep-konsep, prinsipprinsip, dan fakta-fakta saja akan tetapi juga mempelajari dan memahami bagaimana proses pengetahuan itu diperoleh. Pembelajaran biologi seharusnya menekankan pada pembelajaran yang bersifat pengalaman secara langsung.

Penerapan prinsip pembelajaran tersebut dapat dilakukan pendidik dengan memberikan kesempatan kepada peserta didik untuk menemukan dan menerapkan ide-ide kreatifnya, serta mengajarkan peserta didik tersadar menggunakan strateginya sendiri untuk belajar. Pendidik dapat memberikan pelajaran dalam bentuk seperti anak tangga yang berjenjang, sehingga dapat mengantar peserta didik kepada tingkat pemahaman yang lebih tinggi, dengan penekanan bahwa peserta didik sendirilah yang harus mencari, mempelajari, dan menemukan pemahaman tersebut. Bagi peserta didik, pembelajaran harus bergeser dari diberi tahu menjadi aktif mencari tahu. Peserta didik harus didorong sebagai penemu dan pemilik ilmu, bukan sekedar pengguna atau penghafal pengetahuan.

Ajaran agama Islam telah menjelaskan bahwa Allah subhanahu wata'ala mengisyaratkan perintah belajar dan pembelajaran, sebagaimana firman-Nya dalam QS Al-Alaq/ 96: 1-5, dengan terjemahan sebagai berikut: “Bacalah dengan menyebut nama Tuhanmu yang menciptakan, Dia telah menciptakan manusia dari segumpal darah. Bacalah, dan Tuhanmulah Yang Maha Pemurah, yang mengajar (manusia) dengan perantaraan kalam. Dia mengajarkan kepada manusia apa yang tidak diketahuinya." (Departemen Agama RI, 2002).

Berdasarkan ayat di atas mengindikasikan bahwa dalam proses pembelajaran dituntut adanya usaha yang maksimal dengan memungsikan segala komponen berupa alat-alat potensial yang ada pada diri manusia dalam hal ini peserta didik dan pendidik, media belajar, dan materi pelajaran sehingga dapat terbentuk suatu proses pembelajaran. Selanjutnya adalah mengajarkan ilmu yang telah dipahami tersebut, dengan cara tetap memfungsikan segala potensi yang melekat pada diri setiap peserta didik dan pendidik. 
Pada proses pembelajaran penggunaan bahan ajar sangat berperan penting. Satu topik pembelajaran diperlukan sejumlah sumber belajar sesuai dengan jumlah standar kompetensi (Trianto, 2009: 251). Salah satu bahan ajar di Indonesia yang sering digunakan yakni modul. Dalam konteks pembelajaran, pengajaran melalui modul adalah salah satu bentuk bahan ajar yang termasuk dalam kategori mandiri yang pernah ada di Indonesia yang digunakan dalam berbagai penyelenggaraan pendidikan baik formal misalnya sekolah maupun pendidikan secara nonformal.

Berdasarkan observasi dan dokumentasi tahap awal yang dilaksanakan di lokasi penelitian, dengan tujuan untuk mengidentifikasi sumber belajar yang dipergunakan oleh peserta didik kelas VII pada SMP Negeri 2 Bajeng Barat dapat ditarik kesimpulan bahwa sumber belajar peserta didik masih sangat kurang. Dalam proses pembelajaran peserta didik hanya memiliki buku pegangan berupa buku paket yang disediakan oleh sekolah sehingga peserta didik masih memerlukan sumber belajar yang lain. Selain itu, buku teks yang digunakan kurang mampu membantu peserta didik untuk melakukan eksplorasi dalam mengamati dan menghubungkan fenomena-fenomena yang terjadi di lingkungan sekitar peserta didik yang terkait dengan materi terutama materi ekosistem. Sedangkan, kalau dilihat dari nilai Kriteria Ketuntasan Minimum (KKM) untuk mata pelajaran IPA yaitu 75, masih banyak peserta didik yang memperoleh nilai di bawah nilai KKM.

Oleh karena itu, diperlukan suatu upaya yang dapat mengatasinya. Salah satunya, diperlukan pengembangan media pembelajaran berbentuk modul yang dapat membantu siswa memahami konsep pelajaran biologi secara mandiri sesuai dengan tingkat kemampuan peserta didik serta dapat memfasilitasi peserta didik untuk melakukan pengamatan terhadap lingkungannya terkait dengan materi khususnya ekosistem yang dipelajari. Untuk itu, perlu dilakukan penelitian secara mendalam mengenai "Pengembangan Modul Pembelajaran Biologi Pokok Bahasan Ekosistem Berbasis Pendekatan Contextual Teaching and Learning (CTL) untuk Peserta Didik Kelas VII SMP Negeri 2 Bajeng Barat.

Tujuan penelitian ini dilakukan yaitu (1) Untuk mengetahui kebutuhan siswa terhadap pengembangan modul materi pokok ekosistem berbasis pendekatan CTL untuk peserta didik kelas VII SMP Negeri 2 Bajeng Barat. (2) Untuk mengkaji modul hasil pengembangan pada pokok bahasan ekosistem berbasis pendekatan CTL untuk peserta didik kelas VII SMP Negeri 2 Bajeng Barat, (3) Untuk mengetahui kualitas modul materi pokok ekosistem berbasis pendekatan CTL untuk peserta didik kelas VII SMP Negeri 2 Bajeng Barat.

Hasil penelitian ini diharapkan memberikan beberapa manfaat yaitu (1) manfaat teoritis, penelitian ini diharapkan memberikan bahan informasi dan bahan praktis bagi pihak-pihak tertentu yang ingin mengambil manfaat dari penulisan ini. (2) Manfaat praktis antara lain, bagi peserta didik diharapkan dapat membantu peserta didik dalam memahami materi dengan lebih baik, bagi pendidik diharapkan dapat membantu dalam proses penyampaian dan memperjelas materi kepada siswa, dan 
bagi sekolah diharapkan dapat memperkaya sumber belajar alternatif dan membantu implementasi kurikulum 2013 khususnya di SMP Negeri 2 Bajeng Barat.

\section{METODE PENELITIAN}

Penelitian ini merupakan penelitian pengembangan (Research and Development) dengan produk pengembangan yang dikhususkan pada modul tentang materi ekosistem yang telah disesuaikan dengan kurikulum 2013. Lokasi penelitian berlokasi di SMP Negeri 2 Bajeng Barat. Subjek uji coba dari penelitian ini adalah siswa kelas VII E SMP Negeri 2 Bajeng Barat tahun ajaran 2017/2018 dengan jumlah peserta didik sebanyak 32 orang.

Ada beberapa instrumen yang digunakan dalam penelitian ini diantaranya a) lembar validasi yaitu bahan pembelajaran yang digunakan untuk memperoleh informasi tentang kualitas bahan pembelajaran berdasarkan penilaian para validator ahli; b) angket ini bertujuan untuk mendapatkan data mengenai pendapat siswa tentang proses pembelajaran menggunakan modul berbasis kontekstual. Angket ini menggunakan skala Likert dengan 4 kategori penilaian yaitu sangat setuju (skor 4), setuju (skor 3), tidak setuju (skor 2), sangat tidak setuju (skor 1); c) tes hasil belajar dipergunakan untuk mengetahui tingkat penguasaan siswa terhadap materi yang telah diajarkan. Pembelajaran dikatakan efektif jika minimal $80 \%$ siswa tuntas dari KKM (Kriteria Ketuntasan Minimal) dengan ketuntasan individu $\geq 75$; dan d) lembar observasi.

Angket validasi produk dipergunakan untuk mendapatkan data kevalidan dan angket respon siswa untuk mendapatkan data praktis. Tes digunakan untuk mengetahui apakah produk yang dihasilkan dapat memberikan hasil sesuai yang diharapkan. Keefektifan produk ditentukan dengan melihat nilai hasil belajar peserta didik.

Lembar observasi pada penelitian ini yakni untuk mengetahui aktivitas peserta didik selama proses pembelajaran dengan menggunakan modul yang dikembangkan berlangsung. Wawancara digunakan untuk mengetahui permasalahan yang dihadapi dalam proses pembelajaran di SMPN 2 Bajeng Barat. Teknik wawancara yang digunakan adalah wawancara terstruktur. Dokumentasi digunakan untuk mendapatkan data mengenai gambaran pelaksanaan pembelajaran di SMPN 2 Bajeng Barat dan juga hasil dari uji coba modul yang dikembangkan.

Analisis data yang dipergunakan dalam penelitian ini dikelompokkan menjadi tiga, yaitu analisis kevalidan, analisis kepraktisan, dan analisis keefektifan. Masingmasing ketiga analisis tersebut dijelaskan melalui tabel berikut ini:

Tabel 1: Kriteria Kevalidan

\begin{tabular}{cc}
\hline Nilai & Kriteria \\
\hline $3,5 \leq \mathrm{M} \leq 4,0$ & Sangat valid \\
$3,0 \leq \mathrm{M}<3,49$ & Valid \\
$2,5 \leq \mathrm{M}<3,0$ & Cukup valid \\
\hline
\end{tabular}




$$
\begin{array}{cc}
1,5 \leq \mathrm{M}<2,5 & \text { Kurang valid } \\
\mathrm{M}<\mathbf{1}, \mathbf{5} & \text { Tidak valid }
\end{array}
$$

Keterangan: M: Nilai rata-rata kevalidan dari semua validator.

Tabel 2: Kategori Penilaian Respon Peserta Didik

\begin{tabular}{cl}
\hline Nilai & Kriteria \\
\hline $3,5 \leq \mathbf{X i} \leq 4$ & Sangat Positif \\
$2,5 \leq \mathbf{X i} \leq 3,5$ & Positif \\
$1,5 \leq \mathbf{X i} \leq 2,5$ & Cukup Positif \\
$0 \leq \mathbf{X i} \leq 1,5$ & Tidak Positif \\
\hline
\end{tabular}

Keterangan: Xi: Nilai rata-rata responden

Tabel 3: Tingkat Kategorisasi Hasil Belajar

\begin{tabular}{cc}
\hline Tingkat Penguasaan & Kategori \\
\hline $85-100$ & Sangat Tinggi \\
$65-84$ & Tinggi \\
$55-64$ & Sedang \\
$35-54$ & Rendah \\
$0-34$ & Sangat Rendah \\
\hline
\end{tabular}

\section{HASIL PENELITIAN DAN PEMBAHASAN}

Penelitian pengembangan ini menerapkan metode yang berlandaskan pada model 4D yang meliputi empat fase yaitu melalui fase define (tahap pendefinisian), design (tahap perancangan), develop (tahap pengembangan) dan fase yang terakhir yaitu disseminate (tahap penyebaran), pada fase yang terakhir ini tidak dapat dilakukan karena produk yang telah dikembangkan tidak digunakan pada skala besar melainkan hanya digunakan pada satu sekolah saja yaitu pada sekolah SMP Negeri 2 Bajeng Barat.

Kebutuhan peserta didik terhadap modul pembelajaran biologi. Langkah awal sebelum masuk pada tahap pengembangan produk, peneliti melakukan penelitian dengan tujuan untuk mengetahui kebutuhan peserta didik terhadap modul pembelajaran. Teknik yang digunakan dalam menganalisis data kebutuhan prototipe modul pembelajaran untuk peserta didik mengarah pada proses menyeleksi, memfokuskan, dan merespon data yang diperoleh dari lapangan. Data yang diperoleh kemudian dikembangkan menjadi prinsip-prinsip penyusunan prototipe modul. Instrumen yang digunakan berupa angket kebutuhan dan didukung oleh wawancara terhadap wali kelas. Adapun prosedur yang dilakukan pada penelitian ini yaitu:

Pertama, pemahaman awal terhadap materi ekosistem. Berdasarkan data yang diperoleh, sebagian peserta didik menjawab bahwa materi ekosistem itu sulit. Oleh karena itu, peneliti mencoba untuk mengembangkan bahan ajar yang lebih menarik untuk membantu peserta didik mempelajari ekosistem. 
Kedua, kebutuhan adanya modul pembelajaran materi ekosistem. Aspek kebutuhan adanya bahan ajar pembelajaran terdiri atas indikator yaitu (1) ketersediaan bahan ajar ekosistem di lapangan dan (2) tanggapan terhadap modul berbasis CTL. Berdasarkan hasil yang diperoleh dapat disimpulkan bahwa sebagian peserta didik menjawab bahwa keberadaan bahan ajar di lapangan selama ini masih kurang memadai. Oleh karena itu, bahan ajar yang akan dikembangkan peneliti diharapkan dapat menambah keberadaan media sebagai sarana sehingga muncul ketertarikan dan keinginan untuk belajar. Indikator kedua yakni tanggapan terhadap modul pembelajaran biologi berbasis CTL materi ekosistem. Berdasarkan hasil yang diperoleh, dapat disimpulkan bahwa peserta didik sangat setuju dan menginginkan adanya bahan ajar baru untuk membantu mereka dalam mempelajari materi ekosistem.

Ketiga, kebutuhan isi atau materi modul pembelajaran materi ekosistem. Berdasarkan hasil yang diperoleh, sebagian besar peserta didik menginginkan penyampaian materi yang jelas yang disertai dengan contoh-contoh serta bentuk evaluasi yang diinginkan adalah pilihan ganda.

Keempat, aspek komunikasi Visual (tampilan) modul pembelajaran. Berdasarkan data yang diperoleh, untuk indikator pertama, sebagian besar peserta didik menjawab bahwa gambar sangat perlu ditampilkan pada modul. Indikator kedua, peserta didik setuju bahwa gambar dapat membantu dalam pemahaman modul. Indkator ketiga, judul yang dipilih oleh sebagian besar peserta didik adalah "Ayo Kenali Ekosistem di Lingkungan Sekitar". Indikator keempat, warna sampul yang diinginkan adalah ungu. Indikator terakhir, peserta didik menginginkan adanya gambar pada modul.

Kelima, harapan peserta didik terhadap modul pembelajaran materi ekosistem. Secara garis besar, peserta didik mengharapkan bahwa media pembelajaran yang akan dipergunakan sebaiknya menarik dan mampu meningkatkan minat dan motivasi belajar. Peserta didik pun menginginkan materi yang singkat, tidak membingungkan mudah dipahami dan bahan ajar tersebut dapat dipergunakan secara mandiri.

\section{Tahapan Pengembangan Modul Berbasis Contextual Teaching and Learning (CTL)}

\section{Deskripsi Hasil Tahap Pendefinisian (Define)}

Pada tahap pendefinisian ini telah dilakukan observasi ke sekolah sasaran yang meliputi langkah-langkah yaitu: "(1) analisis awal akhir, (2) analisis peserta didik, (3) analisis materi, (4) analisis tugas, dan (5) spesifikasi tujuan pembelajaran". Keempat tahap tersebut diuraikan sebagai berikut:

Pertama, analisis awal akhir, bertujuan untuk mengidentifikasi permasalahan esensial yang dihadapi oleh guru dan peserta didik. Pengumpulan informasi dilakukan dengan observasi lapangan dan studi pustaka. Selain itu, untuk memperkuat informasi, peneliti melakukan wawancara kepada guru IPA Biologi 
pada tanggal 26 November 2016 yang bertanggung jawab di SMP Negeri 2 bajeng Barat. Adapun hasil observasi secara keseluruhan diperoleh data bahwa peserta didik mengalami kesulitan dalam memahami materi IPA Biologi karena materinya banyak dengan keterbatasan bahan ajar, peserta didik kurang antusias dan kurang fokus selama pembelajaran berlangsung dan kurang dikembangkannya atau minimnya bahan ajar yang digunakan di sekolah, hanya berupa buku paket.

Kedua, hasil analisis peserta didik. Pada tahap ini peneliti menganalisis siswa di SMP Negeri 2 Bajeng Barat dengan cara mengobservasi secara langsung peserta didik khususnya pada kelas VII. Peserta didik yang menjadi subjek penelitian dalam uji coba terbatas modul berbasis kontekstual yang dikembangkan adalah peserta didik kelas VII E dengan jumlah 32 orang. Pemilihan kelas ini disebabkan ada beberapa peserta didik yang mendapatkan nilai di bawah Standar Ketuntasan Minimum (SKM) yaitu 50 dan juga ada peserta didik yang mendapat nilai 90 ini menandakan pengetahuannya di kelas VII E heterogen .

Ketiga, hasil analisis konten. Adapun tujuan pembelajaran umum berdasarkan kurikulum 2013 untuk mata pelajaran IPA Biologi SMP kelas VII semester genap, yaitu Kompetensi Dasar (KD) 3.8 disebutkan bahwa: "Mendeskripsikan interaksi antar makhluk hidup dan lingkungannya". Alasan mengambil Kompetensi Dasar ini sebagai objek penelitian karena Kompetensi Dasar ini memuat materi (ekosistem) yang bisa dikaitkan langsung dengan kehidupan nyata siswa.

Keempat, hasil analisis tugas. Pada tahap analisis tugas ini, peneliti menganalisis tagihan tugas yang sering diberikan oleh guru mata pelajaran, dalam hal ini dilakukan proses pengamatan langsung (observasi) di kelas dan melihat tagihan tugas yang diberikan oleh guru kepada para peserta didik.

Kelima, spesifikasi tujuan pembelajaran. Pada tahap ini hasil analisis konten sebelumnya, peneliti melihat RPP dan silabus yang digunakan oleh sekolah tersebut, diketahui bahwa peserta didik diharapkan mampu mendeskripsikan interaksi antar makhluk hidup dengan lingkungannya berdasarkan kurikulum 2013 untuk mata pelajaran IPA Biologi SMP Kelas VII semester genap. Dari hasil observasi tersebut peneliti merumuskan indikator pembelajaran dan tujuan pembelajaran yang mengacu pada kurikulum yang berlaku.

\section{Deskripsi Hasil Tahap Perancangan (Design)}

Pada tahap perancangan ini, langkah-langkah yang ditempuh adalah 1) tahap penyusunan tes; 2) tahap pemilihan media; 3) tahap pemilihan format; dan 4) tahap rancangan awal. Penjelasan untuk keempat tahap tersebut adalah sebagai berikut.

Pertama, penyusunan tes. Berdasarkan analisis konten dan analisis tugas yang telah dijelaskan sebelumnya, maka disusun instrumen tentang tes kemampuan peserta didik yaitu tes hasil belajar berupa soal pilihan ganda yang berjumlah 20 nomor yang masing-masing untuk pretest dan posttest.

Kedua, pemilihan media. Media yang digunakan dalam pelaksanaan pembelajaran biologi dengan pendekatan kontekstual pada materi ekosistem di kelas VII adalah modul yang dikembangkan oleh peneliti dengan mengadopsi beberapa 
buku referensi. Media yang mengoptimalkan penggunaan bahan ajar ini berupa lembar kegiatan peserta didik. Manakala alat bantu yang digunakan dalam proses pembelajaran adalah papan tulis, spidol, penghapus, dan laptop.

Ketiga, pemilihan format. Pemilihan format dalam pengembangan modul pembelajaran meliputi lembar kegiatan peserta didik yang dibuat semenarik mungkin dan dilengkapi dengan komponen-komponen pelengkap, gambar, dan cara kerja serta soal-soal diskusi agar peserta didik tertarik dan termotivasi belajar.

Keempat, rancangan awal. Pada modul ini peneliti mengembangkan satu kompetensi dasar berdasarkan kurikulum 2013 yaitu mendeskripsikan interaksi makhluk hidup dengan lingkungannya. Draft awal modul biologi dengan pendekatan CTL untuk siswa SMP dalam penelitian ini terdiri dari 38 lembar, dimana di dalamnya berisi materi-materi tentang ekosistem, kemudian peserta didik diajak untuk melakukan praktikum dengan pengamatan langsung di lapangan, kemudian terdapat soal-soal untuk menguji pemahaman, dan terdapat pula cara untuk menghitung skor. Selanjutnya dihasilkan modul yang memuat kegiatan belajar materi ekosistem yang mengacu pada kurikulum 2013 disebut prototype 1 yang akan divalidasi oleh para ahli.

\section{Deskripsi Hasil Tahap Pengembangan (Develop)}

Pada tahap pengembangan, tahapan-tahapan yang telah dilalui adalah: 1) tahap validasi modul, dan 2) Tahap pengujian modul. Penjelasan kedua tahapan tersebut sebagai berikut.

Pertama, tahap validasi modul. Buku ajar dikatakan valid apabila hasil analisis sesuai dengan kriteria yang telah ditentukan sebelumnya. Seperti yang dijelaskan oleh Arikunto (2010: 69), sebuah instrumen dikatakan memiliki validitas jika hasilnya sesuai dengan kriterium, dalam arti memiliki kesejajaran antara hasil tes dengan kriterium yang telah ditentukan sebelumnya.

Modul yang dihasilkan selanjutnya divalidasi oleh dua validator yaitu dengan menelaah aspek kelayakan isi modul, penggunaan bahasa, penyajian komponen modul, penyajian pembelajaran, dan kegrafikan. Hasil validasi para ahli digunakan sebagai dasar untuk melakukan revisi modul. Dalam hal ini penulis mengacu pada saran-saran serta petunjuk dari para ahli.

Tabel 4: Hasil Penilaian Validator terhadap Modul yang dikembangkan

\begin{tabular}{ccc}
\hline Aspek penilaian & Hasil Penilaian & Kategori \\
\hline Kelayakan isi & 3,5 & Sangat valid \\
Penggunaan bahasa & 3,12 & Valid \\
Penyajian komponen & 3,5 & Sangat valid \\
Kelengkapan komponen & 3,75 & Sangat valid \\
Penyajian pembelajaran & 3,12 & Valid \\
Kegrafikan & 3,37 & Valid \\
\hline
\end{tabular}




\begin{tabular}{lll}
\hline Rata-rata & 3,39 & Valid \\
\hline
\end{tabular}

Menurut Nurdin (2007: 197) yang menyatakan bahwa apabila nilai hasil validasi dari kedua validator berkisar antara $3.0 \leq \mathrm{M}<3.49$ maka modul yang dikembangkan memenuhi kategori valid. Berdasarkan data di atas, diperoleh rata-rata penilaian validator terhadap modul yang dikembangkan berada pada kategori valid sehingga sudah dapat digunakan dengan sedikit revisi dan telah layak untuk diuji cobakan pada skala terbatas di lapangan. Karena semua aspek penilaian berada pada kategori valid maka modul yang dapat digunakan pada pengembangan selanjutnya, yaitu uji coba lapangan pada pembelajaran di kelas untuk kemudian diukur kepraktisan dan keefektifannya.

Kedua, Tahap Pengujian Modul. Tahap uji coba terbatas ini dilaksanakan di SMP Negeri 2 Bajeng Barat Kelas VII E semester ganjil tahun pelajaran 2017-2018. Adapun jumlah peserta didik berjumlah 32 orang diantaranya 16 orang perempuan dan 16 orang laki-laki. Peserta didik dibagi menjadi 5 kelompok dimana 2 kelompok berjumlah 7 orang dan 3 kelompok berjumlah 6 orang. Uji coba terbatas ini bertujuan untuk melihat seberapa besar keberhasilan dari modul yang dikembangkan.

\section{Analisis Kepraktisan Modul}

Kepraktisan modul yang telah dikembangkan diukur dengan menggunakan instrumen penelitian berupa angket respon peserta didik. Kriteria kepraktisan terpenuhi jika $50 \%$ peserta didik memberikan respon positif terhadap minimal sejumlah aspek yang ditanyakan. Hasil penelitian Nieveen (2013: 4) menjelaskan bahwa produk hasil pengembangan dikatakan praktis jika: 1) praktisi menyatakan secara teoritis produk dapat diterapkan di lapangan, 2) tingkat keterlaksanaan produk termasuk kategori "baik". Karena angket respon yang digunakan menggunakan skala likert dengan 4 pilihan yaitu sangat setuju dengan skor 4 , setuju dengan skor 3, tidak setuju dengan skor 2, dan sangat tidak setuju dengan skor 1 . Kriteria kepraktisan terpenuhi jika kategori penilaian berada pada kategori positif terhadap semua pernyataan yang diberikan.

Berdasarkan hasi uji coba pada pernyataan pertama diperoleh jumlah skor soal yaitu 3.68, pernyataan kedua diperoleh jumlah skor soal yaitu 3.34, pernyataan ketiga diperoleh jumlah skor soal yaitu 3.62, pernyataan keempat diperoleh jumlah skor soal yaitu 3.53, pernyataan kelima diperoleh jumlah skor soal yaitu 3.75, pernyataan keenam diperoleh jumlah skor soal yaitu 3.53, pernyataan ketujuh diperoleh jumlah skor soal yaitu 3.62, pernyataan kedelapan diperoleh jumlah skor soal yaitu 3.78, pernyataan kesembilan diperoleh jumlah skor soal yaitu 3.46, dan pernyataan kesepuluh diperoleh jumlah skor soal yaitu 3.43. Akhirnya diperoleh skor total yaitu 35.74 dengan rata-rata yaitu 3.57 yang masuk dalam kategori sangat positif. Berdasarkan data tersebut dan penelitian sebelumnya yang dilakukan oleh Wahyuni (2015: 40) mengatakan bahwa apabila perolehan skor rata-rata hasil analisis angket 
respon siswa berkisar antara $3,5 \leq \boldsymbol{X i} \leq 4$, maka modul termasuk dalam kriteria kualitatif sangat baik.

Hal ini berarti modul berbasis Contextual Teaching and Learning (CTL), yang digunakan oleh siswa termasuk praktis. Dengan demikian kriteria kepraktisan modul berbasis Contextual Teaching and Learning (CTL), tercapai.

\section{Analisis Keefektifan Modul}

Menurut Mustami dan Dirawan (2015: 924) bahwa hasil belajar akan menceminkan kemampuan peserta didik untuk memenuhi prestasi tahap pengalaman belajar, untuk mencapai kompetensi dasar hasil belajar berfungsi sebagai petunjuk tentang perubahan perilaku yang akan dicapai peserta didik dalam kaitannya dengan kegiatan belajar yang dilakukan, disesuaikan dengan kompetensi dasar dan materi yang dipelajari.

Manakala menurut Trianto (2009: 20) menyatakan bahwa "suatu pembelajaran dikatakan efekttif apabila memenuhi persyaratan utama yaitu 1) persentase waktu belajar peserta didik sangat tinggi dicurahkan terhadap kegiatan pembelajaran, 2) rata-rata perilaku melaksanakan tugas yang tinggi diantara peserta didik, 3) ketepatan antara kandungan materi ajar dengan kemampuan peserta didik, dan 4) mengembangkan susana belajar yang akrab dan positif".

Seperti yang telah dijelaskan sebelumnya bahwa untuk mengukur keefektifan produk yang dibuat, dapat dilihat dari tes hasil belajar. Tes hasil belajar yang diberikan pada siswa berupa soal pretest yang diberikan pada saat awal pertemuan dan soal posttest yang diberikan setelah pembelajaran biologi menggunakan modul berbasis Contextual Teaching and Learning (CTL) pada materi pokok bahasan ekosistem. Selain itu, menurut penelitian sebelumnya yang dilakukan oleh Aminullah (2013: 64) terkait pengembangan modul mengatakan bahwa tes hasil belajar ini juga dilakukan untuk mengukur ketercapaian kompetensi dasar dan indikator terhadap pembelajaran dengan menggunakan modul yang dikembangkan.

Tabel 5: Statistik Skor Hasil Belajar Biologi Menggunakan Modul

\begin{tabular}{lc}
\hline \multicolumn{1}{c}{ Variabel } & Nilai Statistik \\
\hline Subjek Penelitian & 32 \\
Nilai Ideal & 100 \\
Rata-rata & $80.62 \%$ \\
Nilai Maksimum & 100 \\
Nilai Minimum & 60 \\
Jumlah Siswa yang Tuntas & 28 \\
Jumlah Siswa yang Tidak Tuntas & 4 \\
\hline
\end{tabular}

Berdasarkan Tabel 5 dapat dijelaskan bahwa hasil belajar siswa pada kelas VII E SMP Negeri 2 Bajeng Barat terhadap pelajaran IPA Biologi dengan materi ekosistem dengan menggunakan modul yang dikembangkan diperoleh skor rata-rata $80.62 \%$ dari skor ideal 100. Nilai Maksimum yang diperoleh siswa adalah 100 dan nilai 
minimum yang diperoleh siswa adalah 60. Hal ini membuktikan siswa mampu menyerap pelajaran dengan baik dengan menggunakan modul berbasis Contextual Teaching and Learning (CTL) yang dikembangkan.

Berdasarkan hasil penelitian di atas sesuai dengan penelitian sebelumnya yang telah dilakukan oleh Sukarnaeni pada tahun 2010 dengan judul Pengembangan Perangkat Pembelajaran Matematika dengan Pendekatan Realistik pada Siswa Kelas VIIB SMP Negeri 6 Watampone, diperoleh hasil penelitian bahan ajar yang dikembangkan memenuhi kategori valid, praktis, dan efektif setelah diuji cobakan dengan rata-rata hasil belajar siswa dikategorikan baik. Hal ini menunjukkan bahwa modul dengan pendekatan CTL memiliki potensial efek terhadap aktivitas belajar siswa dan hasil belajar siswa sehingga praktis dan efektif digunakan dalam proses pembelajaran. Namun, untuk uji efektifitas terdapat keterbatasan produk karena modul biologi yang dikembangkan untuk uji lapangan hanya diuji cobakan pada skala kecil yakni satu kelas dan belum diuji cobakan dalam skala luas. Selain keterbatasan pada uji coba produk, modul biologi yang dikembangkan ini juga mempunyai kekurangan pada pendekatan CTL, karena setiap peserta didik memiliki kecerdasan, karakter, dan minat yang berbeda. Tidak semua peserta didik dapat memahami dan menyukai isi modul biologi dengan pendekatan CTL.

Hanafiah dan Suhana (2009: 67) menjelaskan bahwa pendekatan kontekstual merupakan salah satu pendekatan pembelajaran yang lebih terfokus pada peserta didik dalam proses pembelajaran, sehingga lebih menstimulus dan memberi peluang kepada peserta didik untuk belajar berfikir kreatif, inovatif, dan untuk mengembangkan potensi yang dimilikinya secara lebih optimal.

Berdasarkan hasil penelitian ini, dapat dikatakan bahwa keefektifan penggunaan modul, selain didukung oleh tes hasil belajar juga dipengaruhi oleh tanggapan peserta didik terhadap penggunaan modul. Selama proses pembelajaran berlangsung peserta didik sangat bersemangat karena adanya proses praktikum yang cukup sederhana dan langsung berkaitan dengan lingkungan sekitar. Namun, dapat memberikan pengetahuan secara langsung dan hal ini boleh jadi disebabkan karena pembelajaran dengan menggunakan modul merupakan hal yang baru. Pada proses pembelajaran sebelumnya peserta didik belum pernah menggunakan media seperti model berbasis CTL ini dalam pembelajaran, sehingga peserta didik tidak merasa bosan terhadap pembelajaran yang ada. Peserta didik antusias dan semangat yang karena lebih memudahkannya dalam memahami materi dan merasa lebih termotivasi untuk belajar dengan mempergunakan modul berbasis Contextual Teaching and Learning (CTL) ini.

\section{SIMPULAN}

Berdasarkan nilai analisis data tentang pengujian modul yang dikembangakan baik validator maupun penilaian tes hasil belajar peserta didik, maka dapat disimpulkan bahwa (1) Kebutuhan peserta didik terhadap pengembangan modul berbasis Contextual Teaching and Learning (CTL) yaitu bahan ajar yang mampu 
mengatasi masalah yang terjadi pada proses pembelajaran. (2) Modul biologi yang dikembangkan menggunakan model 4 -D yang terdiri dari 4 tahap, namun pada penelitian ini hanya sampai pada tahap ketiga. Pelaksanaan pengembangannya dimulai dengan tahap pendefinisian terdiri atas analisis awal akhir, analisis siswa, analisis konsep, analisis tugas, dan spesifikasi tujuan pembelajaran. Pada tahap perancangan terdiri atas penyusunan tes, pemilihan media, pemilihan format, dan menghasilkan rencangan awal. Selanjutnya tahap pengembangan yang terdiri atas validasi ahli dan uji pengembangan, dan (3) Kualitas modul biologi yang dikembangkan terdiri atas kevalidan, kepraktisan, dan keefektifan.

Berdasarkan data uji kevalidan modul dengan revisi sebanyak 3 kali, memenuhi kategori valid dengan skor rata-rata semua aspek penilaian validator 3.39 sehingga layak untuk digunakan. Tingkat kepraktisan modul memenuhi kategori sangat positif dengan perolehan skor rata-rata hasil uji coba kepraktisan yaitu 3.57. Kategori ini menunjukkan bahwa modul praktis untuk digunakan dalam proses pembelajaran. Keefektifan modul yang dikembangkan memenuhi kategori efektif melihat rata-rata ketuntasan hasil belajar siswa sebesar $80.62 \%$.

\section{DAFTAR PUSTAKA}

Aminullah. (2013). Pengembangan Bahan Ajar Biologi Pokok Pembahasan Sistem Reproduksi Manusia dengan Pendekatan Konstruktivisme pada Siswa Kelas XI SMA. Universitas Islam Negeri Alauddin Makassar.

Arikunto, S. (2010). Dasar-Dasar Evaluasi Pendidikan. Cet. II. Yogyakarta: PT Rineka Cipta.

Departemen Agama RI. (2002). Al-Qur'an dan Terjemahnya. Surabaya: Pustaka Agung Harapan.

Fitri, L. A., Kurniawan, E. S., \& Ngazizah, N. (2013). Pengembangan Modul Fisika pada Pokok Bahasan Listrik Dinamis Berbasis Domain Pengetahuan Sains untuk Mengoptimalkan Minds-On Siswa SMA Negeri 2 Purworejo Kelas X Tahun Pelajaran 2012/2013. Jurnal Radiasi, 3(1), 19-23. Retrieved from http:/ / download.portalgaruda.org/article.php?article=97631\&val=614

Glynn, S. M., \& Winter, L. K. (2004). Contextual Teaching and Learning of Science in Elementary Schools. Journal of Elementary Science Education, 16(2), 51-63. Retrieved from https://files.eric.ed.gov/fulltext/EJ798807.pdf

Hanafiah, N., \& Suhana. (2009). Konsep Strategi Pembelajaran. Bandung: Rafika Aditama.

Huang, C. (2005). Designing High-Quality Interactive Multimedia Learning Modules. Elsevier, (29), 223-233. https://doi.org/10.1016/j.compmedimag.2004.09.017

Majid, A. (2013). Perencanaan Pembelajaran. Cet. X. Bandung: PT. Remaja Rosdakarya.

Mustami, M. K., \& Dirawan, G. D. (2015). Development of Worksheet Students Oriented Scientific Approach at Subject of Biology. Man In India, 95(4), 917-925. Retrieved from http:// www.serialsjournals.com/serialjournalmanager/pdf/1456920315.pdf 
Nieveen, N. (2013). Formative Evaluation in Educational Design Research. In T. Plom \& N. Nieveen (Eds.), An Introduction to Educational Design Research. Netherlands: Netzodruk, Enschede. Retrieved from www.slo.nl/organisatie/international/publications.

Nurdin. (2007). Model Pembelajaran Matematika yang Menumbuhkan Kemampuan Meta kognitif untuk Menguasai Bahan Ajar. Universitas Negeri Semarang.

Rafiqah. (2013). Pengembangan Perangkat Pembelajaran Berbasis Konstruktivisme. Cet. I. Makassar: Alauddin University Press.

Rapi, M. (2012). Pengantar Strategi Pembelajaran (Pendekatan Standar Proses). Makassar: Alauddin University Press.

Sadiman, \& Ningsih. (2015). Ilmu Pengetahuan Alam Untuk SMP/MTS. Jakarta: Duta.

Sanjaya, W. (2009). Kurikulum dan Pembelajaran. Cet. II. Jakarta: Kencana.

Sudjana, N., \& Rivai, A. (2009). Teknologi Pengajaran. Cet. VI. Bandung: Sinar Baru Algensindo.

Trianto. (2009). Mendesain Model Pembelajaran Inovatif-Progresif. Cet. 1. Surabaya: Kencana Prenata Media Group.

Trianto. (2013). Model Pembelajaran Terpadu. Cet. V. Jakarta: Bumi Aksara.

Wahyuni, I. (2015). Pengembangan Perangkat Pembelajaran Berbasis Project Based Learning (PjBL) Peserta Didik Kelas X SMA YAPIP Sungguminasa Makassar. Universitas Islam Negeri Alauddin Makassar. 